\title{
Defining corruption and fraud in professional sport
}

\author{
Movlad Khasiyevich Geldibaev ${ }^{\natural}$, Salman Umarovich Dikaev, Kristina Aleksandrovna \\ Krasnova, Nadezhda Yurievna Filatova, and Pavel Valerievich Tsvetkov
}

The North Western branch of the Federal State Budget-Funded Educational Institution of Higher Education "The Russian State University of Justice", Department of Criminal Law, Saint Petersburg, Russia

\begin{abstract}
The first step in systemic addressing the problem of corruption is the comprehension of its scale and nature. This paper explores the extent of fraud and corruption in professional sport. In addition to exploring the forms of legal response, one should mention the improper coverage of the issues of counteracting corruption in professional sport. Fraud and, specifically, corruption in sport is difficult to assess. Most of all-Russian and regional sports federations, physical culture and sports associations tend not to recognise the existence of corruption or fraud in particular sports, or claim that fraud and corruption are under control. Purpose of the study: to explore the extent of corruption and fraud in professional sport. We present a systematic review of literature that explores corruption and fraud, identifying the factors of corruption and fraud in professional sport. To search for relevant studies, the published literature was identified as based on Scimagojr, ResearchGate, ScienceDirect, Google Scholar, Sage Open, in search of relevant studies. Results and novelty: Some sports federations recognise that corruption and fraud are detrimental to fair play and integrity of the professional sport. It is a good practice to develop guidelines for sportsmen in relation to a particular professional sport, which outlines the deeds recognised as corruption and fraud, sets the procedure for their registration, assessment and measures to mitigate and counteract such threats. We have outlined the specifics of motivation for corruption and fraud in professional sport, which differs from the ways of corruption in other segments (like health, education, public service). Professional sports are not characterised by such traditional stimuli for corruption and fraud as poor working conditions and low wages, due to the fact that professional sportsmen are highly paid and their work conditions and social guarantees are much better than those of most ordinary people.
\end{abstract}

Keywords: sports competitions, corruption, fraud, crime prevention

\section{Introduction}

Modern sport is a complex area that includes, in addition to sport-specific relations, labour, financial, economic, administrative, entrepreneurial and other relations [1]. According to the

\Corresponding author: kaf.up@mail.ru 
All-Russian Register of Sports the following sports are developed in our country: traditional (14); all-Russian (140); national (8); applied (21) [2].

The Federal Law No. 329-FZ as of 04.12.2007 "On Physical Culture and Sports in the Russian Federation" defines professional sport as a part of socio-cultural activity aimed at organising and holding professional sports competitions [3].

On 24 November 2020, the Chairman of the Russian Federation Government approved the Strategy for Development of Physical Culture and Sport for the period until 2030, which outlined 11 priority areas covering both amateur and professional sport. The mission of the state in the field of physical culture and sport in the Russian Federation is, among other things, to "ensure transparency and fairness of the competitive process"; our country is viewed in the long term as a leading global sporting power "with economically stable professional sport" [4].

Sporting events are a fascinating and popular spectacle for millions of people. Our country has hosted a number of international competitions in the past few years. Applications to host major international competitions stirring the heightened interest of the public are submitted many years in advance. For instance, the decision to hold the 2018 FIFA World Cup in Russia was taken eight years before the tournament's final, during the selection process, although a number of attempts were undertaken later to reverse this FIFA's decision. But, in autumn of 2014, FIFA firmly rejected all accusations of the corrupt vote in favour of Russia, laid by English representatives [5].

Our research hypothesizes that actions to prevent corruption and fraud are inseparable from defining the core concepts under consideration, relative to particular sports and professional sport in general. Many types of corruption are similar to fraud. Since the said law does not contain any specific anti-corruption provisions, the purpose of the study is to examine the correlation between corruption and fraud in professional sport depending on who enters into corrupt relations, as based on the current theoretical views and provisions (over the last five years) contained in the documents of sports federations. To achieve this goal, we plan to solve the following objectives: analysis of approaches to definition of the phenomena in question at the disciplinary level (relevant regulations of particular federations and sports associations) and the criminal law level (in the criminal law).

\section{Methods}

The review of special literature evidences that in recent years a new direction - sports criminal law - has been actively developing in the criminal law science. However, most of the published works in this area address the issues that relate to the following: definition and disclosure of grounds for criminalisation of deeds related to doping [6-10]; study of illegal influence exerted on results of sports competitions [11, 12]; criminal-law aspects of security of sporting events [13, 14]. Analyzing the essays devoted to corruption and fraud in professional sport, we find confirmation of our hypothesis, as concerns terminological uncertainty. At the same time, we find it difficult to agree with some authors asserting that the term "sports fraud" is so far irrelevant for the present-day Russian law enforcement activities do [1]. We also rely on the data presented by Transparency International in the Global Corruption Report: Sport.

\section{$3 \quad$ Results}

In recent years, the state and the legislators draw attention to the need for the legal regulation of the existing relations in professional sport [15]. 


\subsection{Disciplinary level}

There exist a number of all-Russian and regional sports federations in our country, as well as physical education and sports societies. The all-Russian sports federations, in their turn, are divided into: summer Olympic sports (40); winter Olympic sports (12); non-Olympic sports (80) [16].

The analysis of the Strategy for Development of Physical Culture and Sport for the period until 2030 and of the constituent documents of sports federations evidences the absence of anti-corruption rules in their content, or of any moral guidelines for sportsmen regarding prevention of corruption and fraud. In particular, following a series of anti-doping scandals involving Russian sportsmen, the emphasis in the statutes of national federations is made on ensuring integrity and medical clarity of a respective sport through compliance with antidoping requirements. The authors do not deny the importance of these provisions which, along with the struggle against all forms of discrimination and violence, constitute the basic principles of professional sport. However, the absence of legal anti-corruption provisions creates a certain disciplinary "vacuum" for sportsmen, both experienced and beginners, in virtue of the fact that some federations are not specifically concerned about preventing corruption and fraud, whether among sportsmen, coaches, referees or federation officials. And since such a task has not been set, no respective measures are taken, no programmes are developed to combat corruption and fraud in professional sport in general or in its individual branches.

However, in recent years a number of national sporting associations of foreign countries and international sports associations have included anti-corruption rules in their official documents, or developed particular anti-corruption programmes. For instance, the International Tennis Federation (ITF) approved an anti-corruption programme in the field of tennis for the year 2020 [17].

\subsection{Criminal law level}

As it follows from the Strategy for Development of Physical Culture and Sport for the period until 2030, the peculiarity of the national professional sport is "high dependence of professional league clubs in team sports on state-budget funds and financing by public companies", as compared with the leading world leagues that "function entirely or almost entirely on a commercial basis" [4]. Therefore, the authors deem it necessary to discuss, in this section of the essay, the problems connected with assessing the scale of corruption and fraud in Russian professional sport.

In the first place, no terminological uniformity in the area under consideration should be noted. Since the aforementioned Federal Law "On Physical Culture and Sports in the Russian Federation" does not provide any definition for corruption in the sport we should be guided by the definition of corruption contained in Article 1, Clause 1, of the Federal Law No. 273FZ “On Combating Corruption” as of 25.12.2008 [18].

One more concept is worth mentioning, used in the study of corrupt practice in professional sport [19]. It is the manipulation of sports competitions, as defined by the norms condemning manipulation of sports competitions - contained in Article 3 of the Council of Europe Convention, an international document, that was signed by Russia, but not yet ratified [20]. As noted in the referent literature, "attempts to alter sports results at major sporting events, including the Olympics, world and European championships, play a major role in degrading fairness and spectacularity of sport" [21].

In the autumn of 2015, a round table discussion was held by the Federation Council on the "Issues of financing and combating financial violations in the field of sport", which addressed dubious financial transactions in professional sport: feigned transactions (in the 
form of agreements) involving donations and charitable contributions aimed at evading taxation; sham transactions (in the form of agreements) involving paid advertising services, aimed at "cash-out" and misappropriation; fraudulent transactions (in the form of agreements) involving designing and survey in relation to sports facilities with overestimated cost; tax offences in the area of sports competitions refereeing; inflated agency fees, cash payments (these items become a subject of bribery and kickback); employment contracts with professional sportsmen, coaches and sports officials involving unjustified "golden handshake" based on state-budget funds; transfer contracts with signs of propensity for corruption [20].

\section{Discussion}

We assume that one of the factors contributing to corruption and fraud in professional sport is the archaic nature of sportive structures. Such a phenomenon is characteristic not only of domestic sport structures, but also of international ones. As Transparency International (Global Corruption Reports: Sport) notes, sporting management is often controlled by former sportsmen with little managerial experience, acting within simplistically linear hierarchical organisational models [22]. Nowadays, we face increasing calls for anti-corruption and antifraud measures in professional sport, aimed at establishing fair management systems [23]. Nevertheless, many of these initiatives and measures are still in their infancy and require further strengthening and development.

Fraud is also possible in the processive system of professional sportsmen being transferred from one professional sports club to another [1]. In addition, as long as professional sports remain dependent on state funding, elements of corruption cannot be excluded in spending of state-budget funds at all levels.

\section{Conclusion}

The prospects for further development of professional sport are discussed at the highest level in Russia, which evidences that the state has due understanding of the logjam of issues of legal regulation in professional sport, including by means of criminal law.

Positively assessing the foreign experience of sports associations establishing uniform rules in the domain of preventing corruption, the authors conclude that it would be advisable for all-Russian sports federations to proceed to develop anti-corruption rules with regard for specifics of sport-inherent relations arising in particular sports. The developed rules can be included in their constituent documents, or formalised as particular anti-corruption programmes and memos.

\section{References}

1. K.I. Popov, Ural and Siberia Bulletin of Sports Science, 1(9), 58 (2016)

2. Priznanie vidov sporta, Vserossiiskii reestr vidov sporta [Recognition of sports, AllRussian register of sports]. Accessed on: April 20, 2021. [Online]. Available: https://minsport.gov.ru/sport/high-sport/priznanie-vidov-spor/

3. Federalnyi zakon "O fizicheskoi kul'ture i sporte v Rossiiskoi Federatsii” ot 04.12.2007 N 329-FZ [Federal Law "On Physical Culture and Sports in the Russian Federation" dated 04.12.2007 No. 329-FZ]. Accessed on: April 20, 2021. [Online]. Available: http://www.consultant.ru/document/cons_doc_LAW_73038/ 
4. Mikhail Mishustin utverdil strategiyu razvitiya fizkultury i sporta do 2030 goda [Mikhail Mishustin approved the strategy for the development of physical culture and sports until 2030]. Accessed on: April 20, 2021. [Online]. Available: http://government.ru/docs/40966/

5. A.V. Pochinkin, Manadzhment v sfere fizicheskoy kultury i sporta [Management in the Field of Physical Culture and Sports] (Izdatelstvo "Sport" Publ., Moscow, 2016)

6. A. Henning, K. McLean, J. Andreasson, P. Dimeo, Journal of Drug Policy, art. 102897 (2020). https://doi.org/10.1016/j.drugpo.2020.102897

7. K. Toohey, A. Beaton, Sport Management Review, 20(5), 483 (2017). https://doi.org/10.1016/j.smr.2016.12.004

8. P. Bell, C.T. Have, M. Lauchs, International Journal of Law, Crime and Justice, 46, 57 (2016). https://doi.org/10.1016/j.ijlcj.2016.03.001

9. P. Hurst, C. Ring, M. Kavussanu, Performance Enhancement \& Health, 7(3-4), art. 100155 (2020). https://doi.org/10.1016/j.peh.2019.100155

10. T. Engelberg, J. Skinner, Sport Management Review, 19(1), 1 (2016). https://doi.org/10.1016/j.smr.2015.12.001

11. A. Masters, Policy and Society, 34(2), 111 (2015). https://doi.org/10.1016/j.polsoc.2015.04.002

12. V.V. Saraev, Russian Investigator, 9, 23 (2012)

13. K.A. Krasnova, O roli obmena informatsiei $v$ sisteme mer preduprezhdeniya protivopravnogo povedeniya futbolnykh fanatov [On the role of information exchange in the system of measures to prevent illegal behavior of football fans], in Collection of materials of the All-Russian Scientific and Practical Table "Criminal and criminological problems of combating crime in sports", October 31, 2020, Saint Petersburg, 58-62 (2020)

14. M. Tihanyi, Ugolovno-pravovaya zashchita sportivnykh meropriyatii v Vengrii [Criminal law protection of sports events in Hungary], in Collection of materials of the All-Russian Scientific and Practical Table "Criminal and criminological problems of combating crime in sports", October 31, 2020, Saint Petersburg, 102-109 (2020)

15. V.A. Bondarev, R.D. Zhmurko, Bulletin of the Altai Academy of Economics and Law, 11(1), 196 (2019)

16. Sportivnye federatsii [Sports governing bodies]. Accessed on: April 20, 2021. [Online]. Available: https://minsport.gov.ru/sport/high-sport/sportivnye-federatsi/

17. Tennis Anti-Corruption Program (2020). Accessed on: April 20, 2021. [Online]. Available: https://www.integrityprotectionprogramme.com/assets/TACP.pdf

18. Federalnyi zakon "O protivodeistvii korruptsii” ot 25.12.2008 No. 273-FZ [Federal Law "On Combating Corruption" of December 25, 2008, No. 273-FZ]. Accessed on: April 20, 2021. [Online]. Available: http://www.consultant.ru/document/cons_doc_LAW_82959/

19. G. Brooks, A. Aleem, M. Button, The Extent of Fraud and Corruption in Sport, in Fraud, Corruption and Sport (Palgrave Macmillan, London, 2013). https://doi.org/10.1057/97811372907173

20. Council of Europe Convention on the Manipulation of Sports Competitions. Council of Europe Treaty Series, 215 (2014). Accessed on: April 20, 2021. [Online]. Available: https://rm.coe.int/CoERMPublicCommonSearchServices/DisplayDCTMContent?docu mentId $=09000016801 \mathrm{cdd} 80$

21. I.V. Sokolova, Sports: Economics, Law, Management, 3, 30 (2019) 
22. Global Corruption Report: Sport. Accessed on: April 20, 2021. [Online]. Available: https://transparency.org.ru/images/docs/research/GCR_Sport.pdf

23. P.N. Kobets, K.A. Krasnova, Filosofiya Prava, 3(94), 156 (2020) 